\title{
Reaction Kinetics of Hydrogen and Oxygen Absorption of Titanium Films チタン薄膜と水素・睃素の反応カイネティクス
}

Haruhisa UCHIDA and Eckehard FROMM

Max-Planck-Institut für Metallforschung, Institut für Werkstoffwissenschaft Seestraße 92, 7000 Stuttgart 1, F. R. G. Tel. 0711-2095-1 Telefax 0711-225722

(Received 30, Aug.1989)

(Accepted 20, Sep. 1990)

Thin oxide layers are formed on metal surfaces at ambient temperatures even at low oxygen residual gas pressures in vacuum systems or in inert gas atmospheres. Such oxide layers impede or prevent hydrogen absorption at ambient temperatures. To gain a fundamental understanding of the reaction mechanisms, reaction kinetics of hydrogen and oxygen absorption by titanium films were measured by using the Wagener volumetric method. Theoretical approaches to explain the effects observed are discussed. At the initial stage of the oxidation, ion transport by the Mott potential produced by electron tunneling controls the reaction probability. The pressure dependence of the hydrogen absorption rate indicates that the rate determining step of the reaction is either the dissociation of hydrogen molecules on the surface or the permeation or diffusion of hydrogen atoms in the film.

Key words; absorption, hydrogenation, oxidation, kinetics, dissociation

1.はじめに

大気中はもちろん、高真空中や不活性ガス中においても 金属表面には殁どの場合酸化膜が形成されている。真空漕 から取り出した際にできる酸化膜の厚さは、集積回路の配

線といった薄膜においては、全膜厚の十数パーセントにも なる場合があり、材料の特性、あるいは信頼性に大きな影 響を及ぼすことが考元られる。室温における酸化膜形成の 機構を理解し、その挙動を記述することは興味深いテーマ であり、薄膜を利用する立場から見ても役立つことが多い。

この酸化膜の形成はまた金属表面と水素の反応にも大きな 影響を及ぼす。水素貯蔵用合金を例にとると、水素の吸収・ 放出の繰り返し時における反応速度は、表面污染を伴う場合、 あるいは水素中に酸素や水等の不純ガスが含まれている場合、 数桁以上小さくなったり、あるいは全く反応しなくなったり する 1）。酸化膜や他の化合物膜の水素化に及ぼす影響 については、その機構の解明を含めた定量的な基礎研究はま だ充分になされていない。

そこで表面污染の一例として表面の酸化反応を取り上げ、 水素化物を形成する代表的金属であるチタンを用いて酸化、 特にその初期状態の反応挙動を調べ、さらに酸化反応のモデ ルを用いて反応の律速機構を推定した。またその表面、即ち
数分子層の酸化物を有する試料表面での水素化における反 応速度の圧力依存性より反応の律速機構を明らかにした。

\section{2 . 測定および解析方法}

試料表面に吸着・反応したガス量および反応確率（反応 速度）を求める一方法に Wagenerの休樍法がある 2）。 Fig.1にその概略図を示す。ガス供給系 (reservoir) と試 料の入った反応系 (reciever) とは細管 (capillary)で結 ばれており、両系の圧力及びキャピラリーのコンダクタンス より吸着量及び反応確率が求められる。単位面積あたりの 吸着量を $\mathrm{N}$ とすると反応速度 $\mathrm{v}$ は $\mathrm{v}=\mathrm{dN} / \mathrm{d} \mathrm{t}$ となり， $\mathrm{v}$ と反応確率 $\mathrm{r}$ はれぞれ

$$
\begin{aligned}
\mathrm{v} & =\mathrm{dN} / \mathrm{dt} \\
& =\left[\mathrm{L}\left(\mathrm{p}_{\mathrm{V}}-\mathrm{p}_{\mathrm{R}}\right) \mathrm{V} \cdot \mathrm{d} \mathrm{p}_{\mathrm{R}} / \mathrm{dt}\right] / \mathrm{F} \\
\mathrm{r} & =(\mathrm{dN} / \mathrm{dt}) /\left(\mathrm{dN} / \mathrm{dt}+\alpha \mathrm{p}_{\mathrm{R}}\right)
\end{aligned}
$$




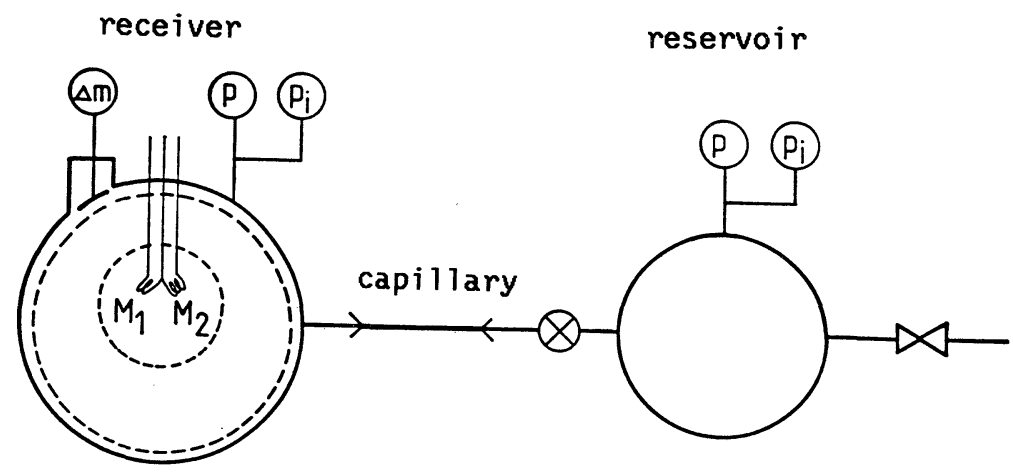

Fig. 1 Volumetric methode. receiver and reservoir are connected by a callibrated capillary; $\Delta \mathrm{m}$ is crystal qartz microbalance, $\mathrm{p}$ and $\mathrm{p}_{\boldsymbol{i}}$ are ionization vacuum gauges, for total and partial pressures respectively. $M_{1}$ and $M_{2}$ are evaporation sources.

となる。ここでLはキャピラリーのコンダクタンス， $\mathrm{p}_{\mathrm{R}}$ p v はそれぞれ反応系およびガス供給系の圧力，Vは反応 系の体積, $\mathrm{F}$ は試料の表面積， $\alpha \mathbf{p}_{\mathbf{R}}$ は圧力 $\mathbf{p}_{\mathbf{R}}$ における ガス分子の単位面積あたりの試料表面に衝笑する数である。 ここで $\mathrm{p}_{\mathrm{v}}$ が $\mathrm{p}_{\mathrm{R}}$ より充分大きければ $\mathrm{v}$ は $\mathrm{p}$ 、 に比例する ので，pvにより vがコントロールできる。また vの変化 に伴う $\mathrm{p}_{\mathrm{R}}$ の変化から反応速度の圧力侤存性が测定てきる。 装置内壁との反応を極力避けるため、装置はコックやフ ランジといった機械的接合部のないガラス製のものを用い た。薄膜蒸着後，蒸着源は反応系より隔嵟される。この方 法の特徴はその場観察で表面解析はできないものの，吸 着量およびガス分子の反応倠率を高轮囲にわたりかなり正 確に測定できる点にある。

超高真空下 ( $<10^{-9} \mathrm{~m} \mathrm{~b}$ a r ) で蒸着法により形成さ れたチタン薄朕試料は, 朕厚 $40 \mathrm{~nm}$, 透過電顕による観 察では粒径 $30 \sim 50 \mathrm{~nm}$ の多結晶脱でった。表面ちら さについては，同様にして作製された薄脱と窒素との実験 より実質面積と見掛け面積の比が $2 〜 4$ でった 3)。 試料蒸着後，試料を水素，または酸素にさらし，あるいは 酸素 と水素を交互にさらし，チタン表面と水素との反応を 調べた。

蒸着源として複数の試料を用意することにより多層構造 のフィルムの作製も可能でありっここでは表面の解離特性 を変化させる上でニッケルをチタン上に形成した場合の効 果を測定した。

\section{3. 結果}

Fig.2 にチタンの体積法による酸化曲線を示す。反応確 率を吸着量の関数として示した。吸着量 Nは分子酋単位 $\left(\mathrm{ML}: 1 \mathrm{ML}=10^{15}\right.$ 分子 $\left./ \mathrm{cm}^{2}\right)$ で示してある。酸素は チタンと最初 $\mathrm{r}_{02}=1$ で反応し， $\mathrm{N}_{02}$ が 10〜14 MLを 越えると徐々に下がり始め, 約 $30 \mathrm{ML} 10^{-4}$ となる。

$\mathrm{r}_{\mathrm{oz}}=1$ でのプラトーの長さは反応速度に依存した。

Fig.3 はチタンと水素の反応を示したものである。清浄 表面において水素は初め $\mathrm{r}_{\mathrm{H} 2}=1$ で反応し， $1 \sim 2 \mathrm{ML}$ 反 応後下がり始め, $10^{-2}$ 付近で定常状態となりプラトーを 示す。このプラトーは $40 \mathrm{~nm}$ のチタンの場合, 約 230 MLの水素分子が反応するまで続き，その後酸素の場合と 同様 $10^{-4}$ 以下になる。定常状態ての $\mathrm{v} の \mathrm{p}_{\mathrm{R}}$ 依存性は圧 力に一次比例でった。Fig.4 にこのときの反応確率，圧

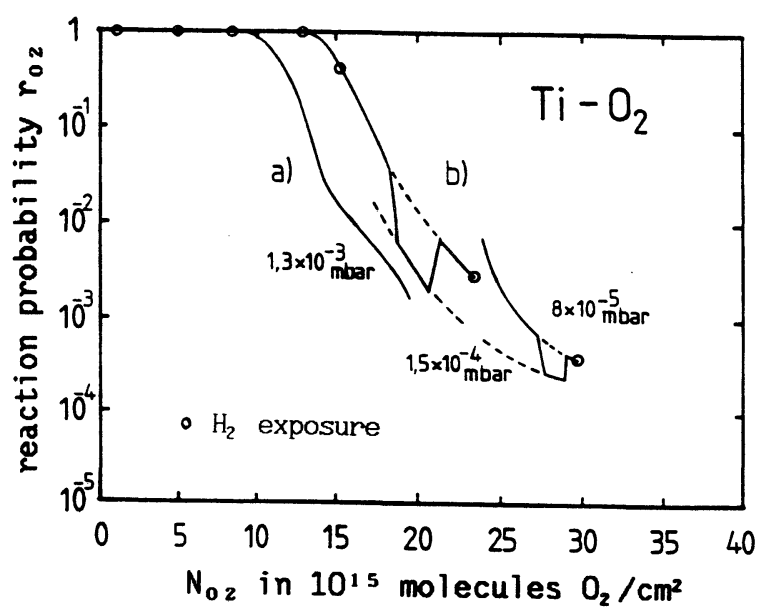

Fig. 2 Oxygen reaction probability, $r_{\mathbf{0}}$, of a titanium film $40 \mathrm{~nm}$ thick. Indicated pressures for gas reservoir are proportional to the reaction rate. Curve b) is measured at alternating exposures of hydrogen and oxygen. 


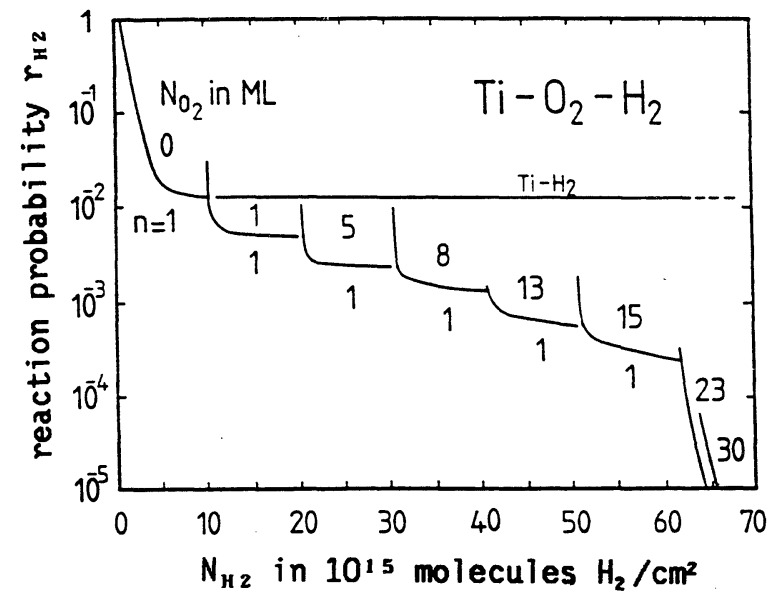

力, 吸着量の時間変化を示した。 $\mathrm{p}_{\mathbf{v}}$ の変化に伴い, $\mathrm{p}_{\mathrm{R}}$ が同じ割合て変化していることがわかる。

チタンの酸化反応の途中て酸素の供給を止め，数層の酸 素層を伴うチタン表面と水素の反応を測定したのが Fig.2 の b）と Fig.3 の階段状の曲線である。酸素量は $1 ， 5$ ， 8, $13,15,23,30 \mathrm{MLO}_{2}$ （Fig.2 曲線 b) て あり， $\mathrm{N}_{02}$ が增加するに従い $\mathrm{r}_{\text {н2 が下がっていくことがわ }}$ かる。15 M L の酸素量までは $\mathrm{r}$ н2曲線はプラトーを示す が，23ML以上の酸素量では試料表面は水素に対して殆
Fig. 3 Hydrogen reaction probability $r_{\mathbf{H}_{2}}$ of a titanium film 40nm thick successively covered with increasing amounts of $\mathrm{O}_{2}: \mathrm{n}$ is the exponent of $\mathrm{p}$ in $\mathrm{v} \sim \mathrm{p}^{\mathbf{n}}$.
ど不活性になる。各プラトーでの v の圧力侤存性は 1 次て あった。

Fig.5 は，Fig.2 のチタンの表面の酸化実験 b ）の後， さらにニッケルを $10 \mathrm{~nm}$ 蒸着し，水素にさらした実験て ある。 $\mathrm{r}_{\text {н2 }}$ 仗 1 から大きく下がるものの, $10^{-3} \sim 10^{-4}$ の間に落ち着いている。またこのとき $\mathrm{v}$ は $\mathrm{p}_{\mathrm{R}}$ の平方根に 比例した。

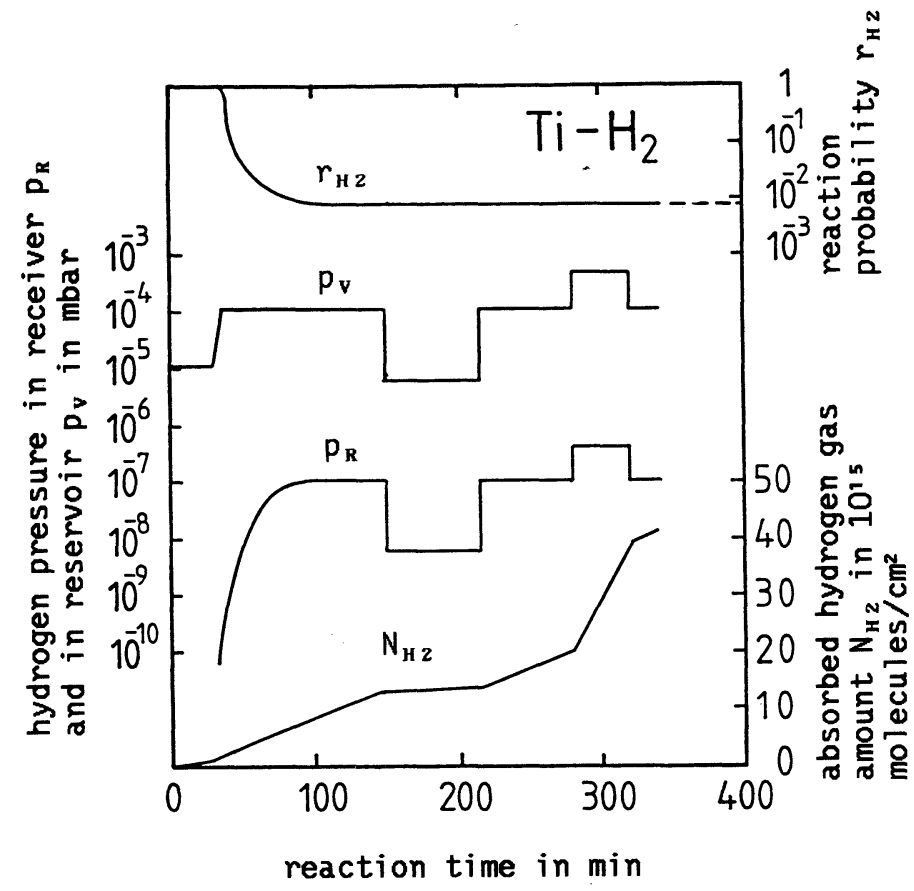




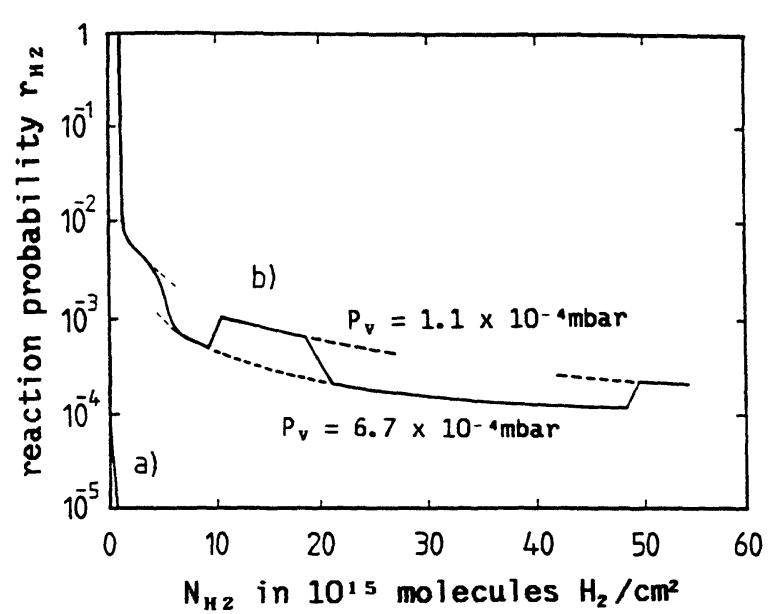

4. 考察

低温での酸化機構はいくつかの機構が混じった複雑 なものである。これまでにFromhold(ref.4)がまとめて いるが、相境界での反応、および拡散するイオン流ま たは空孔流に関する系統だった定量的な取扱いがなさ れていなかった。ここでは先ず酸化反応の初期段階反 応機構を説明するため、Fromholdのモデルをさらに発 展させた著者によるモデル(ref.5,6)を用いて測定結果 に対する解䐆をおこなう。金属と水素の反応について は律速機構と反応速度の圧力依存性について触れ、実 験結果と併せてその機構の推測をおこなう。

\section{$4-1$. 酸化反店}

\section{一般に酸化反応は}

${ }_{x} \mathrm{Me}+{ }_{y} / 2 \mathrm{O}_{2}-\mathrm{Me}_{\mathrm{x}} \mathrm{O}_{\mathrm{y}}$

の形で表される。酸素、金属原子、または空孔は欠陥 として酸化膜を通過して相境界、Me $/ \mathrm{Oxideま}$ たは $\mathrm{Me} / \mathrm{O}_{2}$ にて反応する。

一例として金属がイオンとして膜中を拡散し、酸化 膜表面で化学吸着している酸素と反応する場合、これ は次の样な部分反応に分けられる。
a) 酸素の物理吸着 $\mathrm{O}_{2 \text { (gas) }}-\mathrm{O}_{2 \text { (phys) }}$
b) 酸素イオンとしての化学吸着$$
\mathrm{O}_{z \text { (phys) }}+\mathrm{e}^{-} \longrightarrow \mathrm{O}_{z}^{-}
$$$$
\text { c) 電子の輸送 } \quad \mathrm{e}^{-} \text {(me) }-\mathrm{e}^{-} \text {(surf) }
$$$$
\text { d）格子間金属イオンの生成 }
$$$$
\mathrm{Me}-\mathrm{Me}_{\mathrm{e}}^{+} \text {(ox) }+\mathrm{e}^{-} \text {(me) }
$$

Fig. 5 Hydrogen reaction probability $r_{\mathbf{H}}$ of a titanium film 40nm thick with a) $30 \mathrm{ML} \mathrm{O}_{2}$ and b) with a $10 \mathrm{~nm}$ thick nickel coating on an oxide scale of $30 \mathrm{ML} \mathrm{O}_{2}$ thickness.

e）金属イオンの輸送

\section{f) 酸化璄の形成}

$$
M \stackrel{+}{\mathrm{e}} \text { (ox/Me) } M \stackrel{+}{\mathrm{e}} \text { (ox/gas) }
$$

$$
\mathrm{Me}_{\text {(surf })}^{+}+\mathrm{O}_{2}^{-}(\text {surf })-\mathrm{MeO}_{2}
$$

Fig.6にこれらの部分反応を含んだ酸化反応の機構 を示す。a）は金属がイオンとして、また、b）は酸 素がイオンとして酸化膜を通過する。反応はそれぞれ $\mathrm{Oxide/Me、あるいはOxide/} \mathrm{O}_{2}$ で生じ る。モデルでは酸化膜中のそれぞれの空孔（欠陥）も 金属あるいは酸素イオンと同样に振る舞うものとする。 また酸化膜表面では電子のアクセプターとして $0^{-}$2、 $\mathrm{O}^{--}{ }_{2}, \mathrm{O}^{-}, \mathrm{O}^{--}$が考元られる。

電子流については、酸化物中では充分熱励起された 電子のみが伝導帯を流れるが、酸化膜が充分薄ければ 金属と表面との間に酸化膜を通してトンネル電子電流 が容易に生じる。Cabrera とMott(ref.7) はこのト: ネル電流により表面電荷が維持され、酸化膜中に生じ る強電界（１０５Ｖ/m）によりイオンがよりたやす く輸送されることを最初に見い出した。ここではイオ ン流が律速となる。この電界は化学吸着した酸素イオ ンにより維持されるので、それに必要な表面酸素イオ ンの存在は重要である。酸化膜を通り抜けるトンネル 電流は膜厚約 $3 \mathrm{n} \mathrm{m}$ までは大きいが、これを越えると 指数関数的に小さくなる 4)。この領域ではトンネル 電子電流が全体の反応速度を律速することになり、電 界は著しく小さくなる。厚い酸化膜では熱電子流が大 きくなる。流量は初期のトンネル電流に比べて数析以 上小さいが、温度が高い場合、あるいは長時間酸素に 曝される状態では重要となる。

モデルでは単純化のため、1 種類のイオン流、2 種 


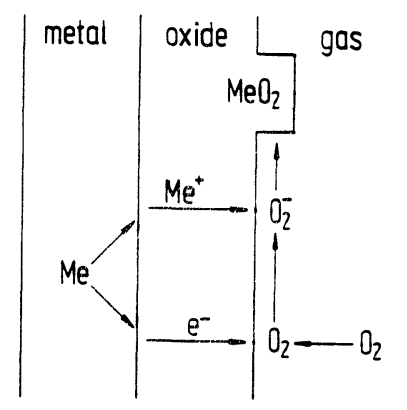

a)

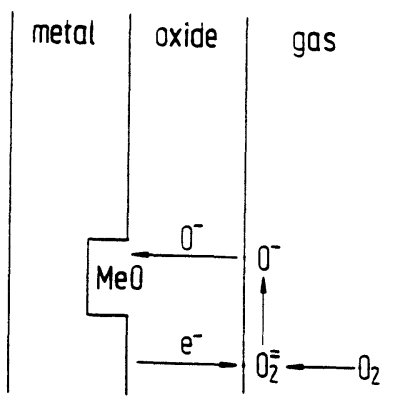

b)

Fig. 6 Partial steps in oxidation: a) metal ion interstitials, b) oxygen ion interstitials prevailing in the oxide.

類の電子流（トンネル電子流と熱電子流）、および 1 種類の化学吸着種について計算をおこなった。実験が 近似的に一定反応速度でおこなわれるため、一定温度 にてイオン流（反応速度）をパラメーターとした。任 意の膜厚においてイオン流と電子流の和が零になるこ とを条件に膜中の各濃度、ポテンシャルを数值計算し てゅき、膜厚にたいするその時の圧力を算出し、イオ ン流との比から反応確率を計算した。

室温での酸化実験は約 $0.1 \mathrm{M} \mathrm{L} \mathrm{O}_{2} / \mathrm{cm}^{2} \cdot \mathrm{min}$ 程 度の速度でおこなわれた。反応確率曲線には反応速度 依存性が見られたが、このモデルを用いて計算した反 応確率の反応速度依存性を Fig.7 に示す。Fig.2 と比 較して良い一致が見られる。Fig.7 では上部に酸化膜 にかかる電位を、下部に反応確率を吸着量の関数とし て示してある。電位差の増加傾向は反応が初期状態で あり、電位差が吸着量と共に増加していくことを示し ている。計算では酸化膜に電位差が生じている状態で はトンネル電子流は充分大きく、イオン流が全体の反 応速度を律速することが明らかとなった。それゆえ反 応確率が 1 である間は表面での気相からの酸素イオン 供給量、即ち表面へ到達する酸素流、または分子から 原子への解離速度が全体の反応速度を律速し、反応確 率が 1 より小さくなると電位差が生じ始め、酸化膜中

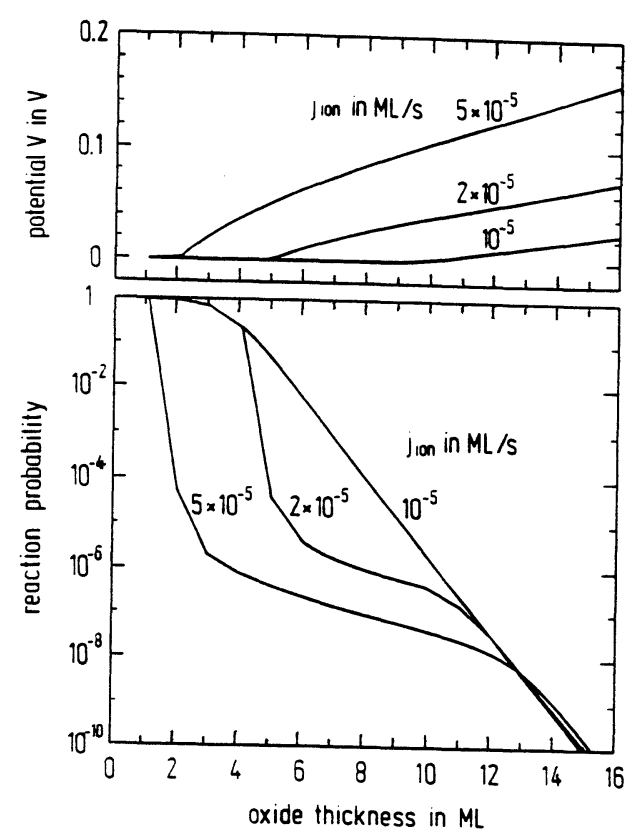

Fig. 7 Reaction probability and potential $V$ as a function of layer thickness $d$.

のイオン流が律速となることが分かる。反応速度が大 きい場合、即ち圧力の高い場合には結果的に化学吸着 しているイオン濃度が増加するので反応確率が 1 での プラトーが短くなり電位差が形成され易くなることが 分かる。

\section{$4-2$. 水素化反応}

金属表面と水素の反応は，次のようにいくつかの部分反 応に分けられる。

g) 物理吸着 $\mathrm{H}_{2}$ (gas) $-\mathrm{H}_{2}$ (Phys)

h) 化学吸着 $\mathrm{H}_{2}$ (Phys) $-2 \mathrm{H}$ (chem)

i ）表面亦ら酸化膜への進入

j）酸化膜中での拡散

k）酸化募から水素化物への進入

1）水素化物中での拡散

m）水素化物から金属への進入

h）金属中での搪散

この中で特に $\mathrm{h}$ と $\mathrm{j}$ 又は 1 の部分反応は他の反応に 比べて遅く、全体の反応速度 $\mathrm{v}$ を律速する。両者とも 熱活性化過程によるものであり、vは活性化過程の手 前の水素濃度に比例する。 $\mathrm{h}$ の反応、即ち解離反応で は物理吸着している水素分子の濃度、 $j$ 以降の反応

（酸化膜の透過または拡散）では、例えば酸化膜の透 過反応速度は化学吸着している水素原子の濃度に比例 
する。これらの濃度と気体水素の圧力の関係はそれぞ れ

$$
\begin{aligned}
& \mathrm{C}_{\text {H2 (Phys) }} \sim \mathbf{p}_{\text {н2 }} \\
& \mathrm{C}_{\mathrm{H}} \text { (chem) } \sim \sqrt{\mathrm{p}_{\text {H2 }}}
\end{aligned}
$$

となる。即ち $\mathrm{v}$ の圧力依存性を測定することにより律 速段階を決定できることになる。このモデル計算に関 する詳しい記述は(ref.8)を参照されたい。

Fig.2 では、チタンの清浄表面と水素の反応におけ る $\mathrm{r}$ 曲線のプラトーは約 $10^{-2}$ に位置している。これ は表面に衝突する 100 個の分子の内 1 個が反応する 量である。ここでのvの圧力依存性が 1 次であること より反応は水素分子の解離が律速していることが分か

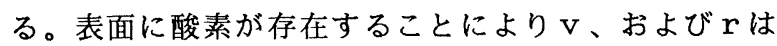
徐々に小さくなっていく。これは表面での解離反応速 度が小さくなっていくことを示している。ここで解離 反応を促進する方法としてニッケルを蒸着することに より $\mathrm{v}$ を増加させることが期待できた（Fig.3）。ここ での $\mathrm{v}$ が圧力の平方根に比例することより、透過・拡 散が律速反応であることは明瞭で、解離反応が内部反 応より速くなったことを示す。律速段階は酸化膜中の 透過が可能性として最も大きいと考えられる。解離反 応についてはその機構を電子相互作用の立場から計算 している Norskovらの仕事がある 9)。水素分子が表 面に物理吸着している場合、表面からの電子が分子内 の非結合軌道に進入することにより解離反応の活性化 エネルギーが著しく小さくなることが見出されている。 酸化膜の表面電子状態と解離反応との関連は興味ある テーマであろう。

\section{5 。まとめ}

体積法を用いてチタンの酸化、及び水素化における 反応のカイネティクスの測定をおこない、それぞれの 反応における律速機構の推測をおこなった。
酸素との反応では $0.1 \mathrm{M} \mathrm{L} / \mathrm{min}$ 程度の一定反応 速度において、反応確率が 1 のときは表面に達する酸 素流、または解離速度が律速し、ro2が下がり始める と酸化膜に電位が生じ始めイオン流が律速する。水素 との反応では、チタン金属表面上または数M L の酸化 物層が存在する場合には水素分子の解離反応が全体の 反応速度を律速する。水素の反応確率が $10^{-5}$ を下回 り、表面が殁ど不活性となった場合、ニッケル薄膜が 触媒として働く。このとき膜内部での透過過程が律速 段階となる。

材料表面とガスとの反応の性質の基礎的な立場から の研究は、例えば触媒の表面污染の問題や、材料の表 面処理プロセスの条件設定等、応用面で役立つことが 多い。

\section{Reference}

1) E. Fromm, H. G. Wulz, J.Less-Common Met. 101 (1984) 469

2) 0. Mayer, Dissertation, Universität Stuttgart (1977)

3) E. Fromm, "Non-Stoichiometric Compounds-Surface, Grain Boundaries and Structural Defects" edited by J. Nowotny and W. Weppner, Kluwer Academic Publishers, Dordrecht, The Netherlands 1989 E. Fromm, V. Grajewski, H. H. Uchida, "Plasma Surface Ingineering" edited by E. Broszeit et. al. DGM Informationsgeselschaft-Verlag, Bonn 1989

4) K. Hauffe, "Reaktionen in und an festen Stoffen", Springer, Berlin 1966

5) N. Cabrera, N.F. Mott, Rept. Phys. 12(1949)

6) E. Fromm, H. Uchida, B. Chelluri, Ber. Bunsenges. Phys. Chem. 87, 410-418 (1983)

7) J.K. Norskov, S. Holloway, N. D. Lang, Surf. Sci. 137 (1984) 65

8) H. G. Wulz, E. Fromm, J.Less-Common Met. 118 (1986) 303

9) H. H. Uchida, E. Fromm J. Less-Common Met. 131 (1987) 125

以上 